\title{
Introduction to BCL Forum
}

\section{Research of PRC scholars on selected topics in Chinese historical linguistics}

\author{
Nathan W. Hill \\ Trinity College Dublin, University of Dublin, Dublin, Ireland \\ nathan.hill@tcd.ie \\ Lai Yunfan \\ Max Planck Institute for Evolutionary Anthropology, Leipzig, Germany \\ khroskyabs@gmail.com
}

Just as much valuable research on the history of French is written in French and important work on the history of Russian is written in Russian, many valuable contributions to Sino-Tibetan linguistics are written in the Sino-Tibetan language in question. There are Newar language publications on Newar, Tibetan language publications on Tibetan, and Meitei language publications on Meitei, but without question the most copious such research tradition is Chinese language research on the history of Chinese. Although the incidence of scholars outside of China who are able to consult Chinese language sources is thankfully high and ever increasing, the vast size of Chinese language scholarship alone still means that the new discoveries and insightful interpretations in this body of research are not uniformly taken into account in Western language scholarship. The language barrier, even if porous, is one reason for the formation of distinct 'camps' on important questions like the number of vowels in Old Chinese. The goal of this BCL Forum is to present critical discussions of the research traditions currently active in the PRC on a selection of important topics in the history of Chinese.

The idea for this Forum arose in the course of a lecture series at Renmin Daxue and other universities in Beijing that Nathan Hill gave in December 2019 in relationship to his then newly published book (Hill 2019). Nathan found that MA and PhD students attending these lectures had valuable insights on a number of topics that his recent monograph treated as unsolved or vexatious. In agreement with the BCL editorial board, a selection of topics was drawn up and a number of early career researchers were invited to submit papers addressing these themes. Dr. Lai Yunfan joined the project when the process of peer-review and editing became too complex for Nathan. We are pleased to be able to here offer three of these papers: "Middle Chinese labial softening” by Gāo Yìpéng 高艺鹏, “From Qièyùn to Guăngyùn: An overview of the Qièyùn series rime books" by Jī Yuè 姬越, and “50o years of Old Chinese phonology: Research on the history of phonological scholarship from the Southern Song to the Ming dynasty” by 趙 昕 Zhào Xīn.

Purely to improve legibility for an Anglophone audience, these three papers all employ Baxter's 1992 reconstructions of Middle Chinese and Baxter and Sagart's 2014 Old Chinese reconstructions. These choices do not constitute an endorsement of any particularities of these systems by either the authors or editors. In addition, the editors have made some effort to unify the translation of Chinese technical terminology across the three papers, but refrained from doing so in a mechanical way that might impair rather than facilitate the reader's comprehension. 
The editors' experience of overseeing this Forum has amply confirmed the initial intuition that the project would be of value. It has not been easy to find an English idiom that does justice to the competing views within Chinese language scholarship that is also comprehensible to an Anglophone non-specialist; we hope that the reader finds our solutions agreeable. Keeping in mind that the topics covered here hardly scratch the surface of the relevant rich and contentious Sinophone scholarship, we hope that others will similarly contribute to increasing scholarly dialogue across traditions of Sino-Tibetan research.

\section{References}

Baxter, William H. (1992). A handbook of Old Chinese phonology. Berlin: Mouton de Gruyter.

Baxter, William H. and Laurent Sagart. (2014). Old Chinese: A new reconstruction. Oxford: Oxford University Press. Hill, Nathan W. (2019). The historical phonology of Tibetan, Burmese, and Chinese. Cambridge: Cambridge University Press. 